\title{
Analysis Effectiveness of the Learning Online During Covid-19, A Case Study of Electrical Engineering Students at Manado State Polytechnic
}

\author{
Maya Munaiseche \\ Manado State \\ Polytechnics
}

\author{
Betsi Rooroh \\ Manado State \\ Polytechnics
}

\author{
Grace Pontoh \\ Manado State \\ Polytechnics
}

\author{
Laela Worotikan \\ Manado State \\ Polytechnics
}

\begin{abstract}
This research aims to analyze the effectiveness of Learning (Online) after Covid-19: Concepts, Platforms, and Implementation of the Electrical Engineering Department students. To describe and measure students' attitudes towards using technology, tool/learning aids, and learning activities using the internet, interactive with lecturers, group learning, and self-study. The application of learning in the network (online) is carried out massively in the future Covid-19 pandemic. Its implementation brings up a lot of new things, especially for areas with minimal internet access. For this reason, it is necessary to conduct a study what are the views of students in carrying out online learning. The study was determined by student perceptions in the implementation of learning online during the Covid-19 pandemic in areas with minimal internet access. The type of this research is qualitative descriptive research, where the research subject is a student at Engineering Department Manado State Polytechnics. This research is done through four stages, namely (1) data collection, (2) data reduction data, (3) data presentation, (4) concluding. The instrument used is a questionnaire/questionnaire consisting of 21 questions. Data analysis was carried out by descriptive. The study results indicate that students have different perceptions of various aspects of the implementation of online lectures. These perceptions include perception of online learning infrastructure by $67 \%$, learning skills online by $78 \%$, perceptions of the quality of online academic interactions by $69 \%$, benefits of online learning by $56 \%$, obstacles faced by $45 \%$, factors supporting online learning by $48 \%$, and expectations of future online learning by $57 \%$. This research concludes that various student perceptions in online education during the Covid-19 pandemic range from infrastructure, quality interactions, and student benefits.
\end{abstract}

\section{Keywords}

Analysis, effectiveness, implementations, learning online

\section{INTRODUCTION}

The concept study that can be used as a solution during the COVID-19 pandemic is online learning. The practice of online education is carried out by various levels of education from elementary, middle, high school to university levels. There are no more learning activities in classrooms as is usually done by educators: teachers and lecturers. The right step but without adequate preparation. The government minimizes the spread of Covid-19 in addition to limiting human encounters in large numbers. According to Anggrawan A. (2019), Face-to-face and online learning models have advantages and disadvantages in supporting student learning styles. Student learning styles represent what students like in learning and affect student learning outcomes [1]. School is a teaching and learning space between students and teachers; activities limit students and lecturers. The direct face-to-face learning process held in every classroom was stopped. The termination of the face-to-face learning process is one of the decisive actions set by the government to break the chain of the spread of COVID-19 through the world of education. [www.kompas.com] the following learning process is carried out using the Distance Learning (PJJ) method. E-learning is an electronic-based learning process used by the education of Manado State Polytechnic. Web-based learning can be accessed at the e-learning Polimdo. All those involved in this online learning activity can $\log$ in through their respective accounts.

Based on the background, the problems raised in this study are to analyze the effectiveness of online learning after covid19 on concepts, platforms and implementations for students majoring in Electrical Engineering to identify the point of online learning after covid-19: the use of e-learning, ideas, media and performance in the Electrical Engineering department

Research Objectives are to analyzing the effectiveness of online learning on concepts, platforms and implementations for students majoring in Electrical Engineering and identify the practice of online learning concepts, media, feature and implementation of online learning during the covid-19 period.

\section{METHOD}

This research is a qualitative descriptive study and describes students' perceptions of online learning by the network. This research was conducted on Electrical Engineering students. The object of study is students' perceptions regarding the implementation of online learning during the Covid-19 period. This research is conducted in four stages, namely (1) data collection, (2) data reduction, (3) data presentation, (4) concluding data collection using two research instruments, namely questionnaires and interview guides. Data reduction in this study will continuously after field research until the information is complete. Data presentation is carried out to display descriptive data from the results of the questionnaire given. The conclusion stage is the final stage of research to answer how students perceive online learning implementation during the Covid-19 period.

The instrument used a questionnaire that consisted of 7 perceptual indicators, which were scattered into 21 questions. These perception indicators are online learning infrastructure, online learning skills, perceptions of the quality of online academic interactions, benefits of online learning, obstacles faced, supporting factors for online learning, and expectations of future online learning.. 


\section{RESULT AND DISCUSSION}

Humans are accustomed to thinking visually or having graphical images in their brains, even though the information received is verbal. Visual perception can affect the forms of imagination in his mind that are influenced by previous knowledge and experience even though verbal messages are conveyed (Abbasi et al., 2020). To be done online learning, lecturers must prepare learning modules.

Modules designed by lecturers must meet the following requirements: (1) have clear, specific, observable, and measurable learning objectives to change learner behavior and (2) the module's content is relevant to the needs of students, society, and the world of education: Work, or the world of Education (Pratiwi, 2020)..

Of course, the modules prepared by the lecturer follow the curriculum and syllabus. The lecture design is the same as the face-to-face lecture design. For example, it takes 16 weeks for a semester, including two weeks for the midterm and final exams. The online mode of learning design is the same as the face-to-face mode. It's just that the difference is online mode learning using internet media (Pratiwi, 2020). Online mode learning is the use of the internet network by students in the learning process. The online mode learning approach has the following characteristics: (1) requires students to build and create knowledge independently (constructivism), (2) students will collaborate with other students in building their knowledge and solving problems together (social constructivism), (3) forming an inclusive learning community, (4) utilizing website media that can be accessed via the internet, computer-based learning, virtual classes, and digital classes; (5) Interactivity, independence, accessibility, and enrichment (Directorate General of GTK Kemendikbud, 2016). Through the online learning model, students have the flexibility to study time. Students can learn anytime and anywhere. Students can interact with lecturers simultaneously, earning interactions. Details of the student perception are presented in Table 1

Table 1. Student Perception

\begin{tabular}{|c|l|c|c|}
\hline No & Student Perception & Point & $\begin{array}{c}\text { Percent } \\
\text { ages }\end{array}$ \\
\hline 1 & $\begin{array}{l}\text { Perceptions of online learning } \\
\text { infrastructure }\end{array}$ & Objectives & $67 \%$ \\
\hline 2 & Online learning skills & Scale 1-5 & $78 \%$ \\
\hline 3 & $\begin{array}{l}\text { Perceptions of the quality of } \\
\text { online academic interactions }\end{array}$ & Objectives & $69 \%$ \\
\hline 4 & Benefits of online learning & Scale 1-5 & $56 \%$ \\
\hline 5 & Obstacles encountered & Scale 1-5 & $45 \%$ \\
\hline 6 & $\begin{array}{l}\text { Supporting factors for online } \\
\text { learning }\end{array}$ & Scale 1-5 & $48 \%$ \\
\hline 7 & $\begin{array}{l}\text { Expectations for online } \\
\text { learning in the future }\end{array}$ & Scale 1-5 & $57 \%$ \\
\hline
\end{tabular}

The understanding of students during online lectures according to data analysis has advantages and disadvantages, are presented in Table $2 \mathrm{a}$, and $2 \mathrm{~b}$ :
Table 2. Student Perception during online

\begin{tabular}{|l|l|}
\hline \multicolumn{2}{|c|}{ Advantages of online learning according to students } \\
\hline no need for preparation & $80,80 \%$ \\
\hline more flexible and relaxed & $72,20 \%$ \\
\hline new experience & $47,70 \%$ \\
\hline Documented and releasable material & $32,20 \%$ \\
\hline Dare to ask questions and discuss & $26,80 \%$ \\
\hline
\end{tabular}

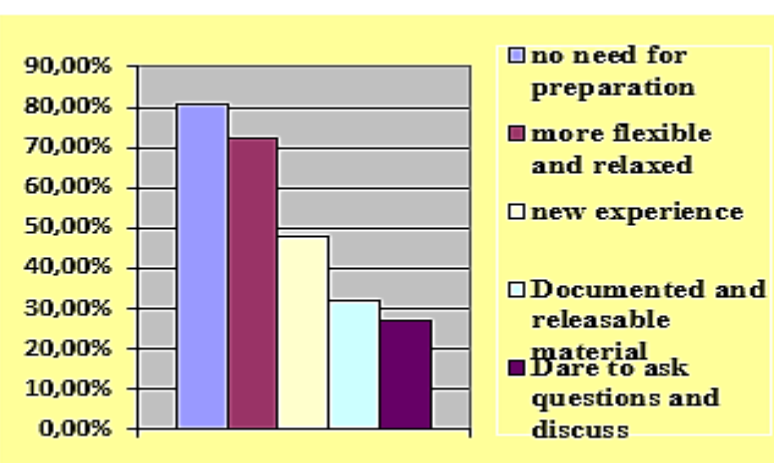

Fig 1: Advantages of the student during online learning

Table 2b. Student Perception

\begin{tabular}{|l|l|}
\hline \multicolumn{2}{|l|}{ Disadvantages of online learning according to students } \\
\hline Internet network & 76,2 \\
\hline Frequent Tasks online & 67,1 \\
\hline Concentration decreased & 63,7 \\
\hline Overload Duty & 61,2 \\
\hline $\begin{array}{l}\text { Lecturers are less interactive and } \\
\text { communicative }\end{array}$ & 26,7 \\
\hline
\end{tabular}

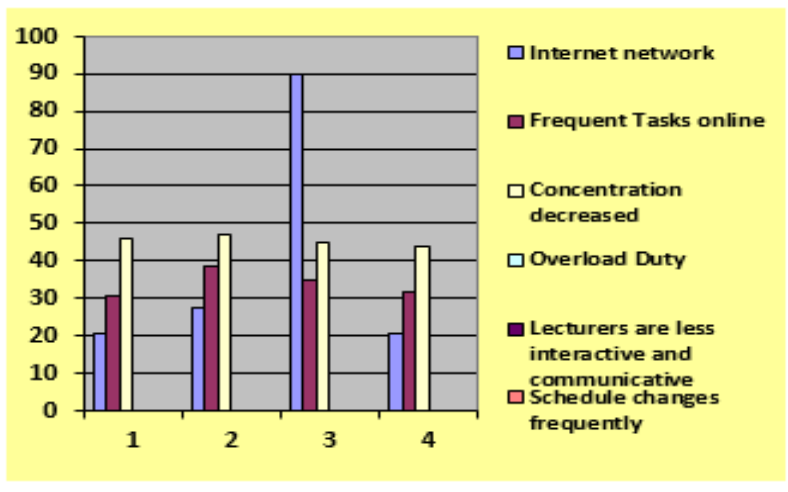

Fig 2 Disadvantages of the student during online learning. 


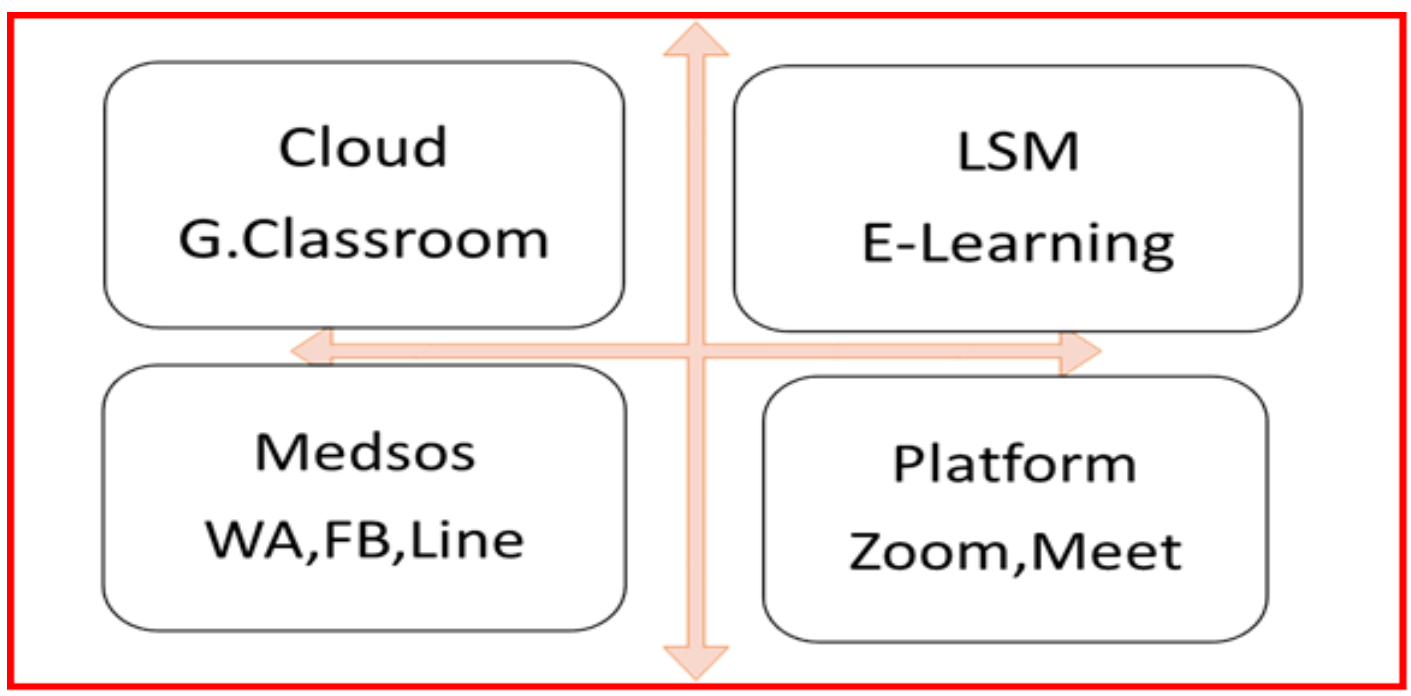

Fig 3: Effectiveness Features of Learning Online

\section{CONCLUTION}

The results of this research conducted show that students have different perceptions of learning online by lectures. These perceptions include perceptions of online learning infrastructure $57 \%$, online learning skills $67 \%$, perceptions of the quality of online academic interactions $78 \%$, benefits of online learning $69 \%$, obstacles faced $56 \%$, supporting factors for online learning $45 \%$, and future online learning expectations of $48 \%$. The positive side obtained from student statements is the ease in carrying out lectures, maximum interaction, good feedback given by the lecturer. However, there are opposing sides, including limited network usage, expensive quotas, and interrupted network electricity. From this research, several studies were found to be used as a reference in researching the future. (1) It is necessary to know the effectiveness of online learning, especially for students in areas with minimal internet, (2) From the perceived constraints of students, it is necessary to develop the best learning mode in minimal internet situations.

\section{ACKNOWLEDGMENTS}

This research was supported by Politeknik Negeri Manado, We thank Director of Politeknik Negeri Manado Dra.Mareyke Allelo MBA, The head center of P3M Politeknik Negeri Manado supporting and provide insight and expertise that greatly assisted this research. Dr. Ir. Jeanely Rangkang, M.Eng,Sc. .

\section{REFERENCES}

[1] Anggrawan, A. (2019). Analisis Deskriptif Hasil Belajar Pembelajaran Tatap Muka dan Pembelajaran Online Menurut Gaya Belajar Mahasiswa. MATRIK: Jurnal Manajemen, Teknik Informatika Dan Rekayasa Komputer, 18(2), 339-346.

[2] Luh Devi Herliandry , Nurhasanah , Maria Enjelina Jurnal Teknologi Pendidikan dkk.
[3] Dai, D., \& Lin, G. (2020). Online Home Study Plan for Postponed 2020 Spring Semester during the COVID-19 Epidemic: A Case Study of Tangquan Middle School in Nanjing, Jiangsu Province, China. SSRN Electronic Journal.

[4] Pratiwi, E. W. (2020). Dampak Covid-19 Terhadap Kegiatan Pembelajaran Online Di Perguruan Tinggi Kristen

[5] Angelina, L. (2020) Jurnal Pendidikan Teknologi Informasi (JUKANTI), 3(2), 27-32). Strategi Pengelolaan Zoom Meeting Dalam Proses Pembelajaran Dimasa Pandemi

[6] Ali Sadikin, Afreni Hamidah, 2020. Pembelajaran Daring di Tengah Wabah Covid19 Studi Kasus . Jurnal Ilmiah Pendidikan Biologi ISSN 2580-0922 (online), ISSN 2460-2612 (print) Volume 6, Nomor 02, Tahun 2020, Hal. 214-224.

[7] Cate Watson Anna Wilson Valerie DrewTerrie Lynn Thompson. 2016. Criticality and the exercise of politeness in online spaces for professional learning The Internet and Higher Education Elseivier Journal Volume 31, October 2016, Pages 43-51.

[8] Dewi, W. A. F. (2020). Dampak Covid-19 Terhadap Implementasi Pembelajaran Daring Di. 2(1), 5561.Firman, \& Rahayu, S. (2020). Pembelajaran Online di Tengah Pandemi Covid-19. Indonesian Journal of Educational Science (IJES), 2(2), 81-89.

[9] Kusuma, J. W., \& Hamidah. (2020). Platform Whatsapp Group Dan Webinar Zoom Dalam Pembelajaran Jarak Jauh Pada Masa Pandemik Covid 19. Jurnal Ilmiah Pendidikan Matematika Volume, 5

[10] Buku Panduan Merdeka Belajar - Kampus Merdeka Direktorat Jenderal Pendidikan Tinggi Kementerian Pendidikan dan Kebudayaan 2020. 